\title{
1. Water allocation in rivers under pressure: a large-scale collective action dilemma
}

Water rights transfers would increase the benefits gained from the use of water and would tend to delay or make unnecessary the construction of new sources of supply ... [but] the fact that no two water rights are identical ... will prevent the development of a market in water rights comparable to the auction market of a stock or commodity exchange. (National Water Commission, 1973: 260, identifying the benefits and constraints on water trading)

The current system is clunky: it's often difficult to get approvals, and protections are not always effective. We will need to develop a more streamlined approach, while taking into account that the water market is much more nuanced than, say, a market for plywood. How and when water moves through the system matters, so rules are needed to facilitate trading and to ensure that it doesn't harm other users or the environment. (Ellen Hanak, New York Times, 29 June 2014, on the state of water rights trading 40 years later in the context of California's drought, 2011 to 2014, and ongoing as of 2015)

\section{INTRODUCTION}

Sustainable and secure access to freshwater is a defining challenge for society. This ancient challenge is becoming increasingly difficult because many of the world's rivers and aquifers are under pressure. Almost 4 billion people will live in river basins experiencing severe water stress by 2050 according to the baseline scenario of the most recent Organisation for Economic Co-operation and Development (OECD) environmental outlook study (OECD, 2012). This is not a distant challenge, however. A 2010 study in Nature concluded that 80 per cent of the global population faces threats to water security, particularly in regions with 'intensive agriculture and dense settlement' and where 'water scarcity accentuates threats to drylands' (Vorosmarty et al., 2010: 556). In this context, the World Economic Forum has identified water crises among the top societal risks in its annual survey of global leaders from 2011 to 2015. Recognition of these threats is growing, and water crises topped the 2015 
global survey as the highest impact risk (World Economic Forum, 2015). Water crises are also positioned as a 'center of gravity' that binds together agriculture, energy, and ecosystems and connects local and global processes through trade, demographic patterns and climate change (World Economic Forum, 2013).

Intensified competition for scarce and variable water supplies requires water allocation institutions - shared rules and norms to establish and allocate property rights to water. These institutions determine how to allocate water across competing uses, reduce and share risks, manage conflicts, and adapt in the face of stress and change. Water allocation institutions include a bundle of property rights governing who can access, withdraw and consume water, and under which conditions. Water allocation institutions also define who manages and reallocates water, and how water's multiple public goods will be provided and sustained (Schlager and Ostrom, 1992; Schlager and Blomquist, 2008; Meinzen-Dick, 2014).

It has been 40 years since the US National Water Commission identified voluntary water transfers as part of the 'future of water policy' (NWC, 1973). Yet the transition to more sustainable and adaptive water allocation institutions remains elusive. This book investigates why progress has proven slower and more uneven than anticipated, and it identifies institutional choices that enhance or reduce the capacity to adapt and accelerate reforms. As the number of uses and values (cultural, economic and ecological) proliferates, so do the stakeholders involved in water allocation and governance, spanning diverse water users, different sectors (irrigation, cities, energy), national and subnational governments, river basin organizations and international organizations, among others. The precise mix of stakeholders is an empirical question, but water allocation institutions increasingly involve decisions with impacts and implications that cut across multiple political boundaries. This heightens the calls for institutions that not only enhance efficiency, equity, sustainability and adaptive capacity, but also promote integration and coherence across multiple values, scales and jurisdictions.

Principles for 'good water governance' and policy prescriptions to achieve more sustainable and adaptive water allocation systems have been developed in tandem with the growing perception that there is a (global) water crisis (Figure 1.1). The emerging paradigms for water governance and water allocation reform have been anchored in local experiences, which have produced a diverse landscape of allocation rules with different mixtures of three ideal types: community-based management (users), markets (water rights trading) and governments (central governments) (MeinzenDick, 2007). Despite the diversity of rules and norms and the importance of local context, global experts and epistemic communities have converged 


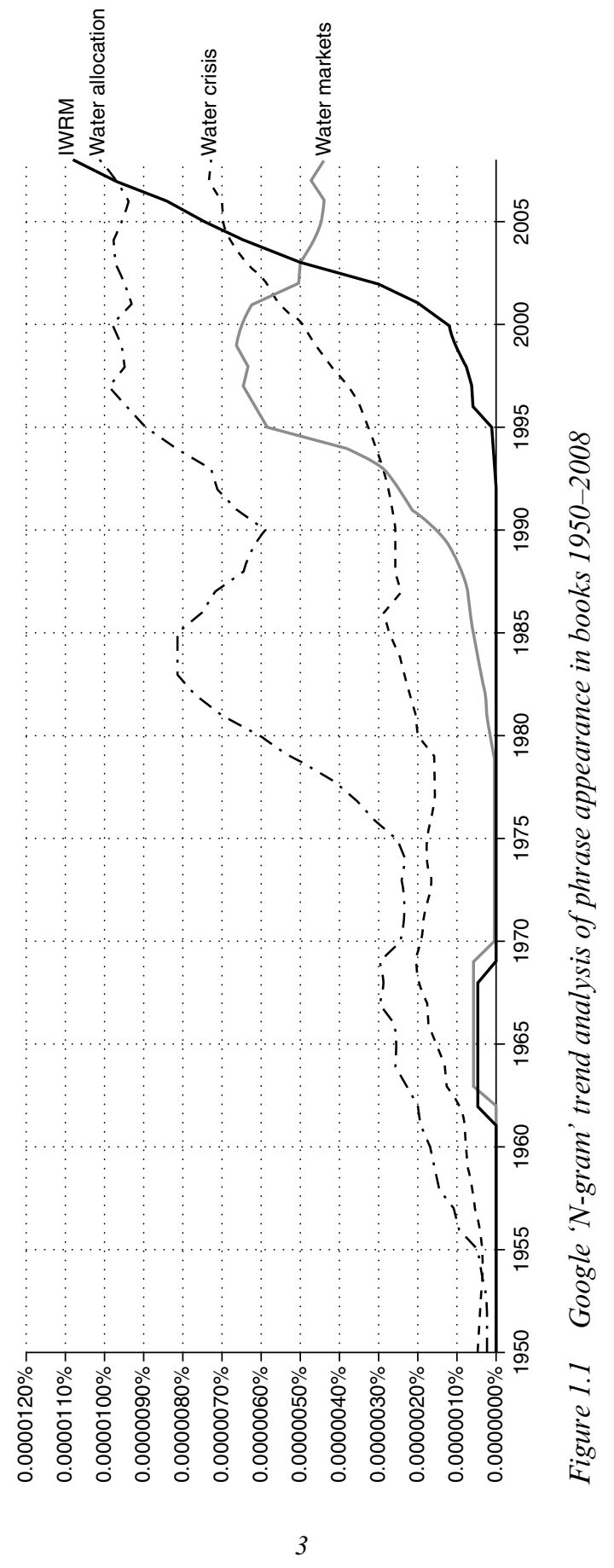

Dustin Evan Garrick - 9781781003862 
on some specific policy tools and approaches, including water markets and integrated water resources management (Conca, 2006). Prominent examples include the principles enshrined by the 1987 Brundlandt Commission on Sustainable Development, the 1992 International Conference on Water and the Environment in Dublin, Ireland ( $a k a$ the Dublin Principles) and the 2005 Millennium Ecosystem Assessment, with the latter dedicating a chapter to policy options to manage freshwater ecosystem services (Millennium Ecosystem Assessment Responses Working Group, 2005).

The challenge of sustainable and adaptive water allocation is particularly pronounced in 'closed rivers' - those already experiencing chronic imbalances between supply and demand, where downstream needs are unmet due to inadequate environmental flows, poor water quality and/ or insufficient dilution flows (Molle et al., 2007). Many of the world's iconic mid-latitude rivers, such as the Colorado, Murray-Darling and Yellow, are closed or closing; a long history of hydropower and irrigation development has been followed by increasing demand by cities, industry and the unmet needs of freshwater ecosystems, often with sharply reduced outflows to the sea (Grafton et al., 2012).

In closed rivers, competition and conflicts over water have prompted efforts to reform water allocation institutions to enhance their equity, efficiency, sustainability, adaptability or, more often, some complex mixture of these multiple objectives. I draw on theory and evidence about collective action, property rights and transaction costs to examine the evolution and performance of water allocation policy in semi-arid transboundary rivers of Western North America and Southeast Australia: large-scale 'common pool' water resources with diverse actors, values and interests.

Theories of collective action examine the conditions favoring or hindering self-organization by actors, as well as the coordination and conflict resolution mechanisms spanning different jurisdictions. However, collective action is costly; transaction costs are the 'economic equivalent of friction' and refer to the financial and other resources required to develop and change institutions, in this case, those governing water access, withdrawal and management (Williamson, 1985: 2). Common pool resources (CPRs) are those for which exclusion is costly and resource flows are 'subtractable': one person's use precludes use by others in the short term, posing a risk of overextraction and collapse; larger CPRs involve more users, jurisdictions and cross-scale trade-offs.

Closed rivers therefore present large-scale commons dilemmas, comprising diverse interests, complex interdependencies and potential for threshold changes driven by interacting social and ecological pressures. This book investigates two prominent institutional responses to these dilemmas often examined separately: water markets and river basin governance. 
I use evidence from in-depth interviews and questionnaires, historical archives and quantitative and qualitative measures of transaction costs to compare institutional design and performance in three river basins: the Colorado, Columbia and Murray-Darling. All three are on the leading edge of global water challenges yet have experienced varying levels of success and diverging trajectories of reform.

\section{THE WATER CRISIS: A CRISIS OF FRAGMENTED GOVERNANCE - LESSONS FROM THE COMMONS}

The 'global water crisis' has been attributed to a variety of factors. Global population has doubled since the 1960s, and hit 7 billion in 2012, with at least 2 billion more people projected by $2050 .{ }^{1}$ This population is increasingly urban and adopting resource-intensive diets that could require a substantial increase in food production by 2050 . The environment has been recognized as a legitimate and economically important water user, yet aquatic habitat associated with 65 per cent of river discharge is compromised (Vorosmarty et al., 2010). Climate change is a threat multiplier with water-related impacts superimposed on chronic pressures and resource scarcity. A $2^{\circ} \mathrm{C}$ increase in global average temperature is projected to increase the global population living in conditions of absolute water scarcity (Schewe et al., 2014).

In this context, the OECD surveyed water governance trends in its member countries and concluded that the water crisis is fundamentally a crisis of governance and policy fragmentation, requiring collective action by water users, sectors, jurisdictions and stakeholders at all levels (OECD, 2011). This is not the first time the water crisis has been equated with a crisis of fragmented governance, as it followed previous declarations by the Global Water Partnership and UN-Water. Nevertheless, the scale and complexity of the challenge are increasing in the context of growing demands, climate variability and resource interdependencies across interrelated food, energy and water systems. The water crisis is therefore a prime example of a large-scale common pool resource governance dilemma.

The governance challenges for water have been framed in terms of the 'tragedy of the commons' (Hardin, 1968). As noted, common pool resources (CPRs) have unique characteristics: high costs of exclusion, making it difficult to prevent new users from accessing the resource; and subtractability, meaning that consumption of resource flows by one user prevents others from doing so until the resource is replenished. Overuse may lead to collapse when the resource stock components of the CPR are 
impaired and the system loses its capacity to replenish resource flows, for example when watershed functions are compromised or when groundwater extraction leads to subsidence.

Water governance challenges arise in part from water's status as a complex 'economic good' with interdependent private and public values and uses each involving different forms of property rights and coordination institutions. Michael Hanemann (2006) considered the thesis that water is different from traditional economic commodities. Water and water infrastructure have public good characteristics; many benefits, such as environmental flows and flood control, are indivisible for most practical purposes and therefore potentially underprovided because people benefit regardless of their contributions. Water is also distinct due to its complex supply characteristics: variability in space and time, mobility, the capital intensity of large water storage and distribution, and heterogeneity across different sources (groundwater, surface water, and so on) and uses. Together these supply and demand characteristics require a level of collective action - and hence transaction costs - that 'simply does not arise with most other commodities' (Hanneman, 2006: 87). As a consequence, property rights to water are comparably costly to define and manage across interdependent private and public uses.

Despite the costs and challenges involved with governing the commons, lessons have emerged from both failed and successful attempts to do so. Nearing 50 years since Hardin's (1968) provocative thesis about the tragedy of the commons, the accumulated empirical evidence demonstrates that collapse is not inevitable despite the collective action dilemmas associated with a multidimensional resource such as water. A body of theory on collective action and institutional change has identified the potential to govern commons sustainably under certain conditions, such as shared norms, small groups, low inequality and clearly defined and understood boundaries around the resource (Cox et al., 2010: 38; Ostrom, 1990). Larger systems such as transboundary river basins pose added complexity, costs and challenges. In an agenda-setting paper in Science in 1999, late Nobel laureate Elinor Ostrom and colleagues (Ostrom et al., 1999) diagnosed the special features of large-scale ${ }^{2}$ commons dilemmas:

1. The challenge of 'scaling up': the cost of collective action often rises with the number of actors.

2. Cultural diversity: diversity involves multiple values and, potentially, less scope for shared interests.

3. Different CPRs are linked: large CPRs involve complex connections between different systems (for example, climate, water, forests). 
4. Accelerating rates of change: global change and disturbances present robustness challenges.

5. Unanimity as the default decision-rule: inertia and lowest common denominator approaches are prevalent when unanimous decisions are needed.

6. One blue planet: unlike local community-based systems, limited alternatives are available if we fail to steward the planet or major systems within it.

\section{INSTITUTIONAL DIVERSITY AND A TALE OF TWO PANACEAS: WATER MARKETS AND RIVER BASIN GOVERNANCE}

Institutions are the "prescriptions that humans use to organize all forms of repetitive and structured interactions' (Ostrom, 2009: 3). 'Institutional diversity' refers to the potential for these prescriptions to be devised and matched to local and regional circumstances. In her discussion of the rules used to allocate CPRs, for example, Ostrom (2009) notes 112 potential allocation rules based on combinations of allocation formulas $(\mathrm{n}=8)$, such as a volume of water per year, and the basis for allocation $(\mathrm{n}=14)$, such as historic use as the basis for appropriative water rights (ibid: p. 222). For large-scale CPRs, multilevel institutions add layers of complexity by combining rules associated with user self-governance, markets, states and even regional and global governance arrangements, with varying levels of coherency and coordination, across types and scales. In this context, it is tempting to simplify the complexity. Institutional blueprints or "panaceas' have been proposed as a one-size-fits-all (or most) cure for complex CPR governance dilemmas. At the same time, there is a growing call to take context seriously in devising and adapting broad principles to local circumstances, as it is hard to predict how the imposition or removal of a single rule or set of rules will affect the performance of the overall governance arrangements.

Ruth Meinzen-Dick (2007) wrote about three prominent panaceas applied in water institutions - states, markets, and users or communitybased management ${ }^{3}$ - and argues that they should be viewed as mutually reinforcing pillars of an 'institutional tripod' rather than mutually exclusive alternatives. To these three types, river basin organizations and integrated water resources management ${ }^{4}$ have emerged as a "nirvana concept' (Molle, 2008), and arguably a fourth panacea that overlays the others (Thiel, 2014). River basin governance addresses the widening range of interests connected to water; the boundaries of rivers or watersheds are 
upheld as the preferred management unit to internalize the externalities of water withdrawal and use.

In the water-stressed and closed river basins of the world, water markets and river basin governance are two panaceas to manage water scarcity and climate variability, often promoted, designed and implemented independently (with the Murray-Darling of Southeast Australia among the first to explicitly coordinate the two).

\section{Panacea 1: Water Markets}

Water markets have received attention since the 1970s as an institutional response to water stress and associated governance and market failures. Water markets are a form of cap-and-trade environmental and natural resource allocation policy. A cap on water diversions establishes limits, ideally based on sustainability criteria. The allocation of water entitlements creates an initial distribution of property rights based on political contests and principles of efficiency and fairness. Trading rules allow voluntary reallocation to enhance efficiency. The appeal of water markets lies in their potential to address competition and manage conflicts over water by using voluntary transactions between willing buyers and sellers to reallocate water. Equally important is the potential for water markets to delay or even avoid costly new supply infrastructure by facilitating more efficient use of existing resources.

From an institutional design standpoint, there are three basic elements underpinning water markets, and related market-based reallocation mechanisms: a cap, an initial allocation, and trading rules to govern reallocation. The establishment of a cap limits the cumulative supply, or consumptive pool, available for water use in a given region. Such a cap is a regulatory choice, triggered by perceptions of scarcity, and ideally based on sustainable limits. A cap means that new water uses cannot be met without a temporary or permanent reduction in existing uses. The cap therefore provides economic incentives to reallocate existing entitlements (because new permits are no longer a viable option to satisfy emerging demands). Increasingly, the river basin is used as the spatial unit for defining a nested set of caps in which local limits are developed within basin-wide constraints to reduce the social and environmental impacts of changing water use patterns. In the absence of regulation, physical limits on renewable water supplies are an implicit cap and can result in the dewatering of rivers and impairment of aquifers. Indeed, the physical closure of basins often triggers the establishment of environmental reserves. Water markets also depend on institutional reforms to establish private, tradable and enforced property rights to water, as well 
as regulatory safeguards to address social and environmental concerns. Therefore, the second element of water market design is water rights reform. Tradable water rights - the ability to buy and sell well-defined water use entitlements - enable voluntary reallocation among water users. In theory, price signals are used in lieu of administrative or court decisions to cue shifts in water use patterns that maximize productivity as availability and preferences change.

Water markets and cap-and-trade water allocation reforms are hardly novel or recent. It has been 40 years since the National Water Commission encouraged reallocation to 'increase the benefits gained from the use of water and ... delay or make unnecessary the construction of new sources of supply' (NWC, 1973; Congressional Research Service, 2009). Even in 1973, market-oriented reallocation hinged on effective governance and robust institutions. Proposed water allocation reforms implied a single institutional transition, or 'set-up' period, to complete market-enabling reforms by creating water rights registries, adopting trading rules, reducing legal barriers, and establishing water supply projects to handle storage and distribution (Congressional Research Service, 2009). These early arguments for voluntary water reallocation via market mechanisms in the 1970s were followed in the early 1990s by 'free market environmentalism', in which private, tradable and exclusive property rights were the solution to resource scarcity and environmental pollution problems as part of a natural progression toward more economically efficient resource allocation institutions (Anderson and Leal, 2001); for a critical view of the logic of efficient property rights to water, see for example Rose (1990). The scholarly community has developed an abiding interest in water markets with major works assessing the emergence (Saliba and Bush, 1987; Howe et al., 1990; National Research Council, 1992; Rosegrant and Binswanger, 1994; Easter et al., 1998), maturation (Bennett, 2005; Olmstead, 2010; Grafton et al., 2011) and future (Anderson et al., 2012; Maestu, 2013; Glennon, 2010; Easter and Huang, 2014) of water markets. A profound gap, however, has appeared between the initial logic of environmental markets and the reality on the ground. In the intervening years, onthe-ground experience has revealed that cap-and-trade water allocation reforms are more complex than initially envisioned (Neuman, 2004).

Critics of free-market environmentalism bemoaned early prescriptions as 'over-simplistic, misleading and hyperbolic' due to the 'failure of markets to allocate effectively environmental resources because of information costs, externalities, public goods and strategic behaviour' (Blumm, 1992: 372). The unfulfilled promise of some experiments with water markets and the challenges of using voluntary water transactions to resolve conflicts between public and private uses led Bauer (2004) to 
equate market reforms with a siren song that uses deceptive allure to trap its victims. Writing about the use of market-like water rights acquisition for environmental restoration in the US Pacific Northwest, Neuman (2004) captures this disconnect between the promise and progress succinctly: 'that was then, and this is now'. A more nuanced and mature conception of market environmentalism has developed in this period, comprising five interrelated elements: privatization, commercialization, environmental valuation, marketization and liberalization of governance (Bakker, 2014).

A pragmatic middle ground between unqualified success and abject failure has emerged in which water markets and voluntary water transactions have an important, yet complementary, role to play in enhancing the flexibility and adaptability of water allocation institutions. On the one hand, it is evident that water markets play an important role in water allocation in societies, economies and environments as diverse as Australia, Canada, China, Chile, South Africa and the Western US. On the other, the trading activity remains a fraction of the potential anticipated in most of these regions as recently as the early 1990s. The Australia experience in the Southern Murray Darling is the exception - where up to 40 per cent of water allocations in the Southern Murray are traded in a given year (Grafton and Horne, 2014). However, water trading in the MurrayDarling casts the lack of activity in the other semi-arid regions into sharp relief. Despite intense competition for water across agriculture, cities and ecosystems, for example, the California water market has grown only to five per cent of total water use by 2012 due to a range of complex regulatory and infrastructure issues (Hanak and Stryjewski, 2012).

Realizing the benefits of water trading depends on strong institutions and ongoing institutional adaptation from the community to river basin level and beyond. This nuanced governance view of water markets is epitomized by the comments from Ellen Hanak promoting voluntary water transfers as an important response to shortages during California's severe drought conditions in 2014. It also echoes early observations in the Southern Murray-Darling. Writing after the first decades of marketoriented institutional reforms in the Murray-Darling, Challen (2000) concluded that water markets cannot be considered as 'self-maintaining' allocation options that operate smoothly after a single set-up period. Instead, water markets require continuous and sequentially more complex institutional transitions (Carey and Sunding, 2001; Garrick et al., 2013). The evaluative criterion of water allocation institutions in this context must be multidimensional and dynamic as captured by the concept of adaptive efficiency, as discussed in Chapter 2. 


\section{Panacea 2: River Basin Governance and IWRM}

The pervasive externalities and interdependencies associated with water allocation require multi-level and transboundary governance arrangements for coordination, conflict resolution and/or collaboration across political borders. The river basin scale has been upheld as the natural unit for management. In the Murray-Darling, for example, water markets have been accompanied by several decades of river basin planning and interstate agreements. River basin governance contributes directly to market-enabling institutional frameworks through auditing, capping, allocating and trading water rights; it also addresses a range of public goods and other water governance objectives related to sustainability and adaptation. The Murray-Darling therefore demonstrates that water rights reforms are necessary but insufficient for sustainable and adaptable water allocation policy. Robust and adaptive governance arrangements are needed for multi-jurisdictional planning and conflict resolution that combine water markets with strong local, state, federal and river basin institutions.

The coordination of upstream-downstream trade-offs in river basins is a challenge as old as civilization, yet river basin closure heightens interdependencies, as outlined below. As a result, several influential international bodies have promoted river basin governance, and its close cousin, integrated water resources management (IWRM), which together form another prominent panacea, revealed by the n-gram in Figure 1.1. Close scrutiny shows a spike in attention to IWRM in the mid-1990s, which coincided with the agenda and principles set out at the Dublin Conference on Water and the Environment. The Dublin Principles of 1992 were arguably the high-water mark of attention and commitment to the river basin as the preferred scale for water management. The action agenda called for efforts to protect aquatic ecosystems and noted that 'integrated management of river basins provides the opportunity to safeguard aquatic ecosystems, and make their benefits available to society on a sustainable basis' (ICWE, 1992). Even more noteworthy was the assertion that the river basin is the 'most appropriate geographical entity' for planning, management and conflict resolution. Much like the early ideas about water markets, however, for IWRM and river basin governance, that was then and this is now.

Scholars and practitioners have noted a range of justifications for developing or retaining water management at other scales; political jurisdictions are socially constructed and contested in relation to diverse values and interests, with different politics and economies of scale (Thiel, 2014; Blomquist and Schlager, 2005). The critiques of river basin governance 
and IWRM fall under four main categories (Thiel, 2014). First, the physical boundaries of catchments, watersheds, aquifers and river basins are not always clearly specified, particularly for large basins. As one example, for most practical and management purposes, the Darling River is a distinct system from the Murray, and several major tributaries of the Darling only contribute to the Murray in wet years. The situation for aquifers is even more complex, with several layers of shallow and deep aquifers overlaying each other with varying levels of interactions in parts of the Colorado River. Second, even when the biophysical boundaries are clear, problems of institutional fit exist when political borders are not aligned with the basin and aquifers (Mostert et al., 2008; Moss, 2004). Third, these mismatches are not inherently bad because many water management issues are addressed at other scales due to the politics involved (Molle, 2009, 2008). This aligns with another popular prescription which gained popularity in the early 1990s in the context of the European Union: subsidiarity, or the notion that decisions should be taken at the lowest level possible, but no lower (Marshall, 2007). As a consequence of the first three reasons, efforts to achieve comprehensive and integrated management at the river basin scale are constrained by transaction costs. As Schlager and Blomquist (2008) note, institutional development is costly and human rationality is bounded.

As with water markets, a middle ground has emerged between the extremes of abject failure and unmitigated success in the form of polycentric governance arrangements. Polycentric governance arrangements feature multiple independent centers operating in conflict, competition and/or cooperation with one another (Ostrom et al., 1961; Andersson and Ostrom, 2008; McGinnis and Ostrom, 2012); the transaction costs of coordination are a limiting factor affecting the degree of coherence and integration, both within (horizontal) and across (vertical) levels of governance. Marshall (2005) elaborates the twin concepts of subsidiarity and complementarity to convey the assignment and coordination of governance tasks across levels. Subsidiarity refers to the principle of assigning governance tasks at the lowest level possible, while complementary higher-level institutions are needed to coordinate tasks that span multiple political boundaries due to externalities or economies of scale (Marshall 2005). Efforts to scale up water markets and sustainable water allocation involve a nested set of formal and informal institutions to provide multiple water-related public goods; however, the costs and politics of institutional development mean that that an overarching river basin authority may not be either necessary or desirable. 


\section{PROBLEM STATEMENT}

Water allocation in closed rivers presents 'wicked problems' (Rittel and Webber, 1973). The framing of the problem is in dispute, solutions have unintended consequences, and positive feedback contributes to lock-in, which makes learning and subsequent adaptations costly. The two panaceas introduced above share a similar arc - from promise to pitfalls to pragmatism - which reveals a gap between the theory and evidence of institutional change in water allocation and underscores that institutions are not free. Transaction costs are high, often prohibitively so, contributing to path dependent and incremental change that may fail to keep pace with society's evolving preferences and values. Transaction costs ${ }^{5}$ refer broadly to the resources (money, staff, time and so on) required for collective action to develop, implement and adjust property rights and adopt institutional changes. I examine two linked dilemmas: the allocation of common pool water resources, and the provision of water-related public goods at multiple scales. Transaction costs can impede otherwise desired policy reforms, locking resource allocation into historic and maladaptive patterns. Transaction costs ultimately stem from multiple underlying factors shaping water allocation, including historical, geographical and technological characteristics. Understanding the nature and sources of transaction costs is therefore integral to effective policy design and institutional adaptation.

The goal of this book is to make transaction costs visible, and examine the relationship between transaction costs and institutional change in water allocation reform. I argue that the path toward sustainable and adaptive water allocation reforms involves substantial, sustained and multilevel investments in governance capacity. I elaborate a conceptual framework for analyzing the transaction costs involved in water allocation reform, which allows me to understand the factors that enhance or reduce capacity for adaptation. I draw property rights theory, transaction costs economics and common pool resource governance to understand the evolution and performance of water allocation reform, at the intersection of water markets and river basin governance. I measure and analyze transaction costs in market-oriented water rights reform and multijurisdictional water management institutions to identify factors enhancing or reducing 'adaptive efficiency' (North, 1990) - an overarching performance criterion aimed at building long-term capacity to adapt to evolving preferences and values in a context of complexity, periodic shocks, feedbacks and pervasive and deep uncertainty (see Chapter 2). I argue that water markets are not self-maintaining allocation systems (Challen, 2000) and that transaction costs help us to understand why this 
is the case. I show how the performance of water markets and river basin governance institutions depends on a sequence of institutional transitions that address collective action dilemmas at a range of scales - from local water rights reform to coordination institutions for basin-wide planning. Transaction costs analysis can thereby help public policy scholars to identify institutional design principles and policy lessons to inform complex water allocation trade-offs in a rapidly changing world. Through a comparative analysis of three prominent case studies, I identify design and sequencing strategies that minimize the costs of implementation, build capacity to cover necessary costs of periodic transitions, and limit the risk of decisions that lead to lock-in and unnecessarily constrain future adaptation.

\section{AUSTRALIA AND WESTERN NORTH AMERICA AT THE LEADING EDGE}

Intensified competition for scarce and variable freshwater resources have made Southeast Australia and Western North America important international examples of semi-arid transboundary rivers in federal political systems. The Colorado and Columbia Rivers of Western North America and the Murray-Darling Basin of Southeast Australia face similar water allocation challenges: competition for scarce freshwater, climate variability and change, unmet environmental needs and upstream-downstream trade-offs across subnational and, in the Columbia and Colorado, international borders. There has also been a long-standing and mutual interest in exchanging lessons between western North America and Southeast Australia. Over a century and a half of irrigation development, economic growth and diversification, and adaptation to climatic variability have made these regions laboratories for institutional reform - both successes and challenges. The environmental consequences of past development have left the needs for fish, wildlife and ecosystem services unmet.

The story of Australian Alfred Deakin's late nineteenth century visit to the US is a major milestone and entry point in the history of mutual learning between the Western US and Australia. Deakin was a major figure in Australian history in the late 1800s and early 1900s. A vigorous proponent of federation and Australia's second prime minister, he took a strong interest in irrigation development, travelling to the US and South Asia in the early 1880s for a Royal Commission study on water supply. Water supply challenges were critical for economic development and irrigation settlement in the fledgling federation. However, the political economy of water allocation and management required costly collective action to 
organize capital investment and manage irrigation systems, not only by private enterprise but also by irrigation districts and territorial governments across Southern Australia.

Deakin travelled to the US to learn from its experience with similar challenges of irrigation development and governance. Unlike with Europe and Asia, he considered 'the parallel between Southern Australia and the Western States of America as complete as such parallels can well be', due to 'the close resemblance of the peoples, their social and political conditions, and their natural surroundings' (Deakin, 1885, 11-12).

Notwithstanding this strong analytical and policy basis for comparison, Deakin found one major area of divergence between the Western US and Australia: the role of government versus private enterprise in irrigation development and management. In the Western US, Deakin concluded that the government had abdicated its regulatory duties, at both state and federal levels. Doing so, he believed, gave rise to multiple, often conflicting and contested, irrigation development approaches and allocation rules; a situation of institutional diversity that produced chaos rather than coherence in his estimation.

Deakin perceived state inaction as a fundamental institutional design flaw, which can now be viewed through the lens of transaction costs, property rights and coordination institutions. The Western US experience was a vivid warning to Australia of the consequences of state inaction and the corresponding risk that prohibitive transaction costs would thwart future reforms. Deakin described a 'web of litigation' that paralyzed investment and created debilitating uncertainty in the US, which remains an apt description even today. Transaction costs were not an abstract concern; for example, one irrigation canal had estimated annual litigation costs of more than $£ 4000$ (in 1880s pounds) associated with efforts to define water rights and avoid dangerous legal precedents (Deakin, 1885). Despite pockets of innovative water allocation reforms (which I discuss later in this book), fragmented institutional arrangements have persisted in the Western US. The path-dependent effect of past decisions on future reforms is the focus of Chapter 3.

Deakin's visit was a pivotal point in Australia's water development and subsequent reforms. The privatization and fragmentation of water allocation systems in the US prompted Deakin to promote a coherent policy before 'vested interests become too deeply involved' (Deakin, 1885: 21-22). Deakin strongly recommended that the state maintain control over water supply and require measurement to prevent confusion and crippling uncertainty.

The risk of tyranny by vested interests has proven more difficult than expected to combat in Australia, despite Deakin's foresight. Contemporary 
efforts to establish sustainable diversion limits in the Murray-Darling have involved proposals to reduce water use, triggering political resistance and stronger norms of private property rights, echoing the concerns Deakin encountered in fledgling irrigation settlements of the Western US. The experiences of the Murray-Darling and Western US have therefore remained the focus of continued comparison. In both regions, the problems of irrigation development are joined by additional pressures: sectoral competition, climate variability, environmental demands and split sovereignty within a federal political system. Transaction costs analysis can yield new insights into this connected history, recent reforms and future prospects.

My comparison of the Colorado, Columbia and Murray-Darling river basins follows the logic of most similar systems comparisons. Controlling for the many political, cultural and environmental characteristics shared by the three basins, I examine the evolution and performance of institutional design choices in market-based water rights reform and river basin governance in terms of transaction costs and adaptive efficiency, emphasizing the interaction and trade-offs across multiple performance criteria (efficiency, legitimacy, equity, sustainability) over time and space.

\section{WATER ALLOCATION IN CLOSED BASINS}

The concept of river basin closure frames the water allocation challenges in the Murray-Darling and Western US. Molle et al. (2010) define river basin closure as conditions in which downstream commitments are not met; closure is a function of societal choices about dilution, flushing and environmental flows. Basin closure highlights hydrological connections between upstream uses and downstream impacts of irrigation technology, storage infrastructure and groundwater use. Social and economic impacts of basin closure include externalities of local interventions; changes in water use patterns to meet new demands may come at the expense of existing uses or users, including environmental flows (Molle et al., 2007). In short, basin closure refers to the human causes of water scarcity as demands and development strain finite and variable water supplies.

Basin closure can be related to the economic conception of water outlined above. Water resources comprise stock (public good) and flow (common pool, private) components that are interdependent (Figure 1.2). Flow components include the renewable supplies that support human consumptive uses, and stock components include water requirements to maintain freshwater ecosystem functions and processes that sustain renewable supplies. Overextraction of surface water flows and groundwater can 

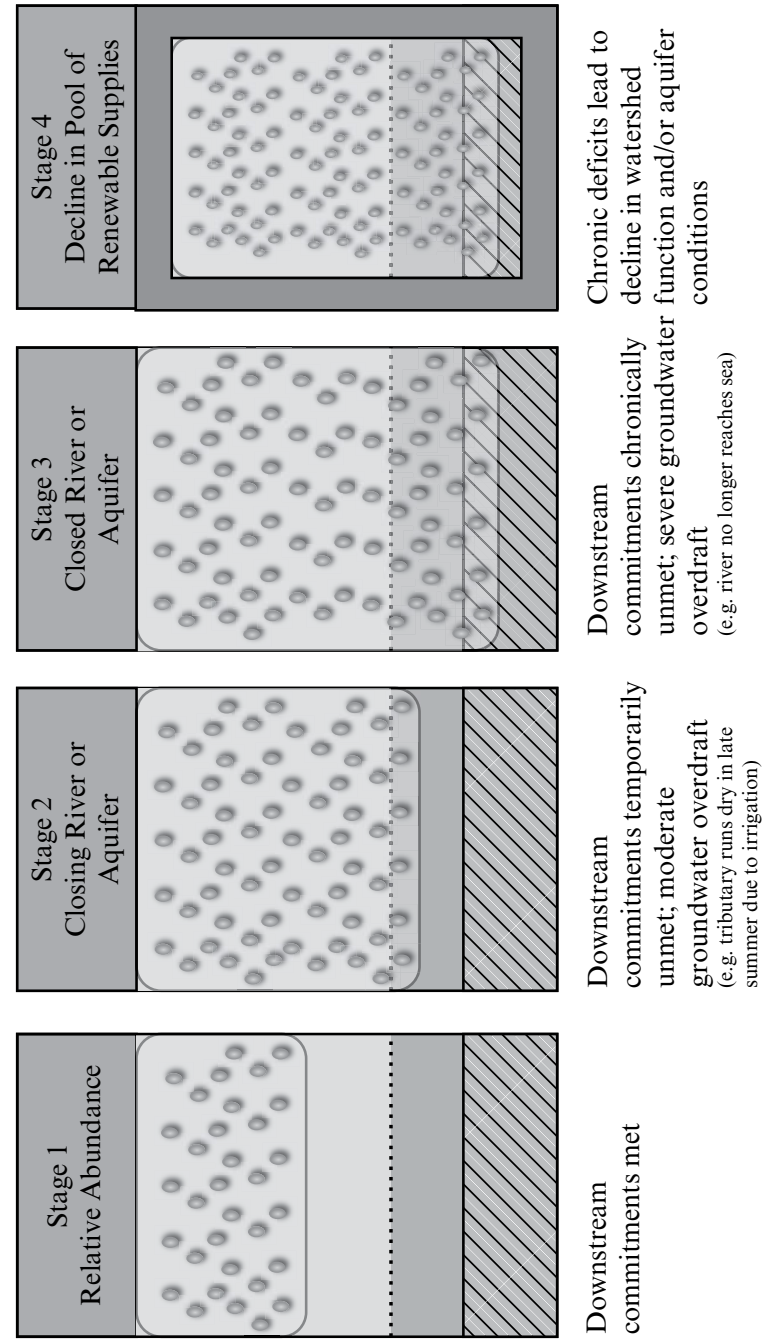

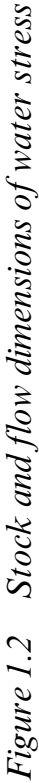
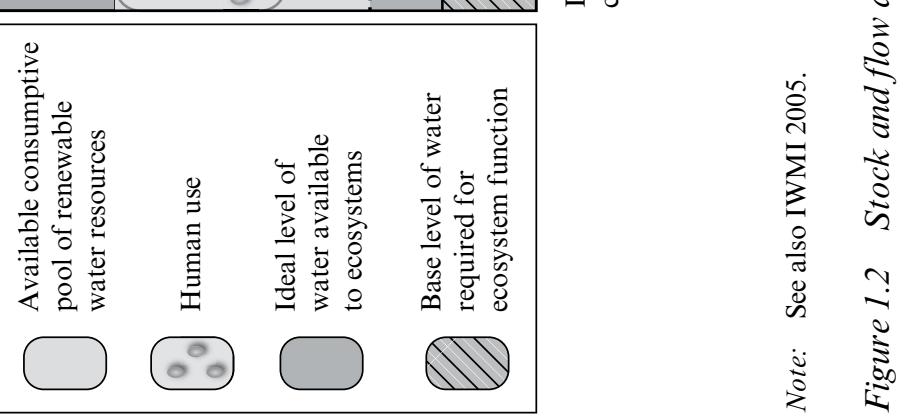
degrade river basin and aquifer conditions and diminish their capacity to replenish, such as when subsidence or changes to forest hydrology decrease renewable flows. As the water consumption for human uses increases, the consumptive pool may periodically (stage 2 in Figure 1.2) or chronically (stage 3 ) exceed ecological limits, causing long-term reduction in renewable supplies as watershed conditions deteriorate or aquifers subside (stage 4). The water allocation reform challenge for a closed basin entails all elements of the water market logic: (1) tradable water rights to manage the consumptive common pool; and (2) a cap to establish, maintain and adapt diversion limits.

\section{A STORY OF THREE RIVERS}

This book focuses on the three examples of closed (or closing) river basins: the Colorado River, Columbia River and Murray-Darling River. These basins are significant examples and relevant comparisons for several reasons. They are closed basins because either: (1) the river does not reach the sea in some years (Colorado, Murray-Darling) in part due to upstream storage and diversions, or (2) tributaries fail to reach the main 'stem' of the river due to seasonal dewatering when peak irrigation demand coincides with the natural low flow in the hydrograph in late summer (Columbia).

River basin closure in these basins is a function of competition for finite water supply between irrigation, cities and hydropower production. The effects are magnified by climatic variability, including seasonal variability and drought extremes. The former makes irrigation necessary, while the latter contribute to supply uncertainty and water storage projects that have downstream impacts. Finally, the basins are large and shared by multiple states in federal countries. Federal countries distribute authority across multiple territories and divide responsibilities between federal and state levels; this creates a situation of split sovereignty with authority shared by multiple independent states, which complicates coordination at the river basin level to manage the upstream-downstream interactions prevalent in closed river basins. In the cases of the Colorado and Columbia Basins, they are also shared by two countries, US-Mexico and US-Canada, respectively, which adds to the large-scale collective action challenge and, hence, transaction costs.

In addition to these shared challenges, the emergence of environmental demands unites the three basins. Action was taken in the Columbia first to address the consequences of irrigated agriculture and hydropower on endangered salmon fisheries. The market-based response has involved public and non-profit water rights acquisitions from willing landowners 
(irrigation water users) to restore streamflow-dependent habitat and reconnect tributaries with main stem rivers.

\section{THE GEOGRAPHY OF RIVER BASIN CLOSURE}

\section{Colorado River}

The Colorado River (Figure 1.3a) straddles seven states in the US and two in Mexico $\left(637100 \mathrm{~km}^{2}\right)$, as well as several Indian tribes, cities and irrigation districts. It has supported extensive irrigation development (4.5 to 5.5 million acres of irrigated agriculture), hydropower production and rapid urban growth for up to 40 million people in the major population centers of the Western US (US Bureau of Reclamation, 2015). The average natural flow in the gauged record (1906-2008) at Lee Ferry is 18500 gigalitres (GL). This average obscures high stream-flow variability: the low and high flows (6930 GL and 31200 GL) were recorded in 1977 and 1984, respectively. Upstream reservoirs - concentrated in Lakes Powell and Mead - store up to four years of the basin's annual mean runoff to buffer against climate variability and sustained drought conditions, which are a prominent feature of the observed and paleoclimate hydrologic records (Woodhouse et al., 2006). The once vast delta ecosystem has declined due to the combination of upstream reservoirs and diversions. Projected climate change impacts include decreases in runoff, earlier snowmelt runoff and more severe droughts.

In the United States, the Colorado River Compact of 1922 apportioned water between states. Compacts are interstate apportionment mechanisms authorized by the US Congress under constitutional authority (specifically the commerce clause) and with the character of federal law (National Research Council, 2004; National Research Council, 2007). There are more than 20 in the US, and the Colorado Compact was the first. The Colorado River Compact divided the basin into two sections. The upper division states (UDS) include Colorado, New Mexico, Utah and Wyoming, and the lower division states (LDS) include Arizona, California and Nevada. The interests of each state within the UDS and LDS differ, although they will occasionally negotiate as a bloc. Mexico has a separate entitlement which was reserved in the 1922 Compact and then formalized by an international treaty in 1944. In total the 1922 Compact and 1944 Treaty commit at least 20.3 billion $\mathrm{m}^{3}$ per year (20300 GL) to the upper division, lower division and Mexican states. These commitments have never been fully developed due to hydrological, engineering and environmental constraints; nevertheless, water use grew steadily 


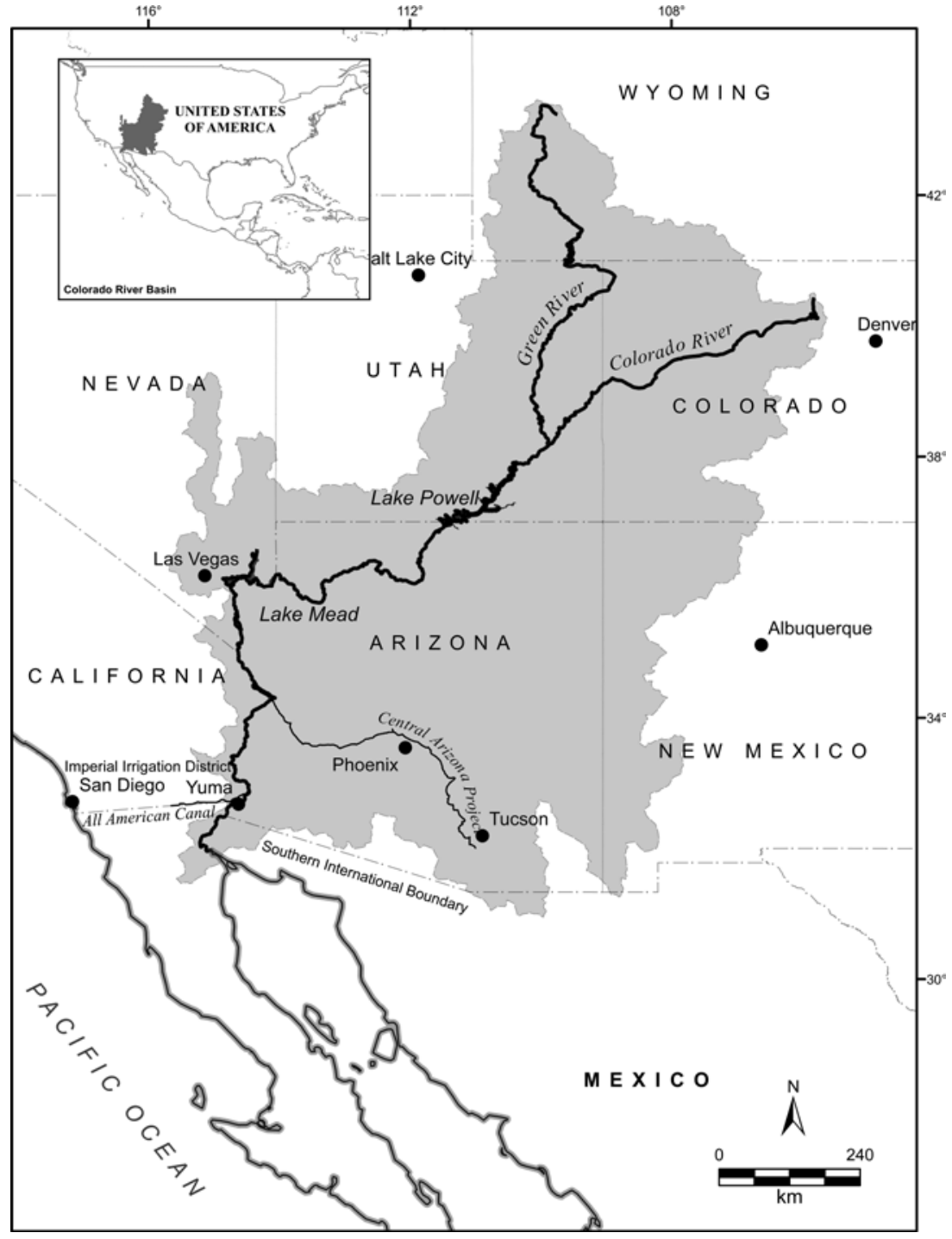

Figure 1.3a Colorado River

during the twentieth century until the early 2000s, when the Quantification Settlement Agreement required California to curb its water use to comply with its surface water entitlements, as specified by the 1963 landmark Supreme Court decision in Arizona v. California. 


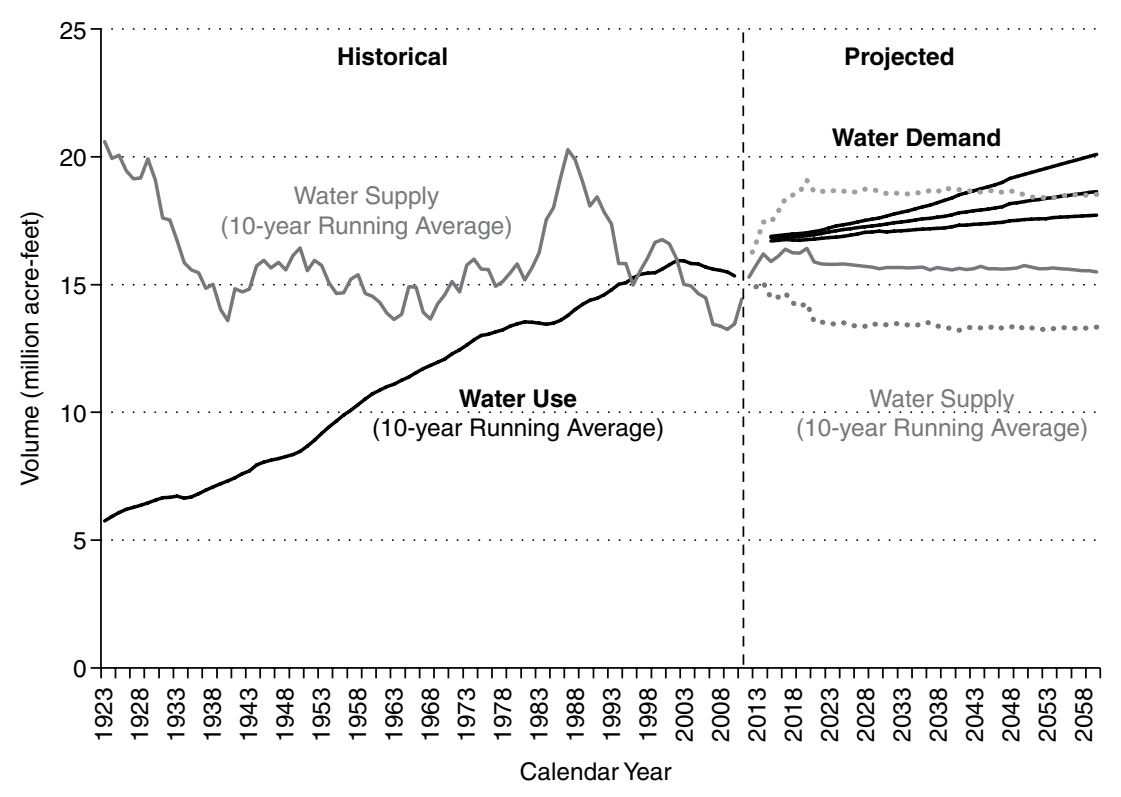

Source: US Bureau of Reclamation (2012).

Figure 1.3b River basin closure in the Colorado River Basin: long-term supply and demand trends

There is a chronic imbalance in lower basin deliveries from Lake Mead, which has been described by journalist John Fleck as a 'structural deficit' with total outflows and losses of approximately 12.6 billion $\mathrm{m}^{3}$ and inflows of only approximately 11.1 billion $\mathrm{m}^{3}$. The annual imbalance is buffered by reservoir storage, but this cushion has been depleted during sustained drought. Long-term demand (ten-year moving averages) intersected with long-term supply in 1999 and eclipsed it by 2002 (Figure $1.3 \mathrm{~b}$ ), depleting the storage buffers from full capacity to approximately 40 per cent as of October 2014 during an unprecedented sequence of dry years from 1999 to 2014 (US Bureau of Reclamation, 2013). These early interstate apportionment agreements are a prime example of path dependent river basin trajectories, despite a recognition of supply variability and overallocation even prior to the Compact's negotiation and certainly after the mega-drought of the 1950s. The Colorado is unique as the only major interstate river in the Western US with direct federal oversight by the Secretary of Interior, who acts as rivermaster. The US Bureau of Reclamation is the lead federal agency, derived from its historical role 
developing the basin's infrastructure. Its role has evolved from infrastructure developer to operations and maintenance. With this shift comes an increasing focus on multistakeholder water planning to address endangered species, climate variability and future growth (DOI, 2007; US Bureau of Reclamation, 2012).

\section{Columbia River}

The Columbia Basin (Figure 1.4a) is one of the most developed rivers in Western North America with more than 200 dams supporting an average of 3 million acres of irrigation; 16000 megawatts of hydropower; a population of more than 7 million with increasing development in the rural, semi-arid interior; and a salmon fishery with high ecological, cultural and economic significance. A series of 31 dams generate hydroelectric power through the Federal Columbia River Power System (FCRPS). Like the Colorado, the Columbia straddles an international border, but between the US and Canada. The basin drains almost $700000 \mathrm{~km}^{2}$ across seven US states, one Canadian province and a number of First Nations and tribal reservations. The Snake, Deschutes, Clearwater, Salmon and Willamette Rivers form important tributaries to the mainstem, while the John Day remains the longest free-flowing river in the basin (that is, without dams).

The Columbia River Basin is comparable in size with the Colorado in terms of drainage area but not in volume. The river discharges into the Pacific Ocean west of Portland, Oregon, after descending $820 \mathrm{~m}$ over $2000 \mathrm{~km}$ from its headwaters in British Columbia, Canada. It has an average volume at the Dalles Dam of 165 billion $\mathrm{m}^{3}$, an order of magnitude higher than the Colorado (NPCC, 2014). The annual average inflows make the Columbia the fourth largest river in North America by volume (National Research Council, 2004). However, like the Colorado and Murray-Darling, stream flow is characterized by spatial and seasonal variability due to a snowmelt dominated hydrograph. Prior to river basin development, 75 per cent of annual runoff occurred during the late spring and summer and only 25 per cent during the fall and winter. This seasonal variability has led to efforts to develop the river through the FCRPS, which has transformed the river's hydrology (flattening out seasonal variability), geomorphology and ecology. Tributaries upstream of these reservoirs still experience seasonal variability. Chronic seasonal water deficits in the tributaries occur in late summer (August, September), when peak agricultural use coincides with natural low flows after snowmelt (Figure 1.4b).

The Columbia is managed by a 'patchwork quilt' of laws, policies and jurisdictions, with allocation authority vested at the state level (Schoessler 


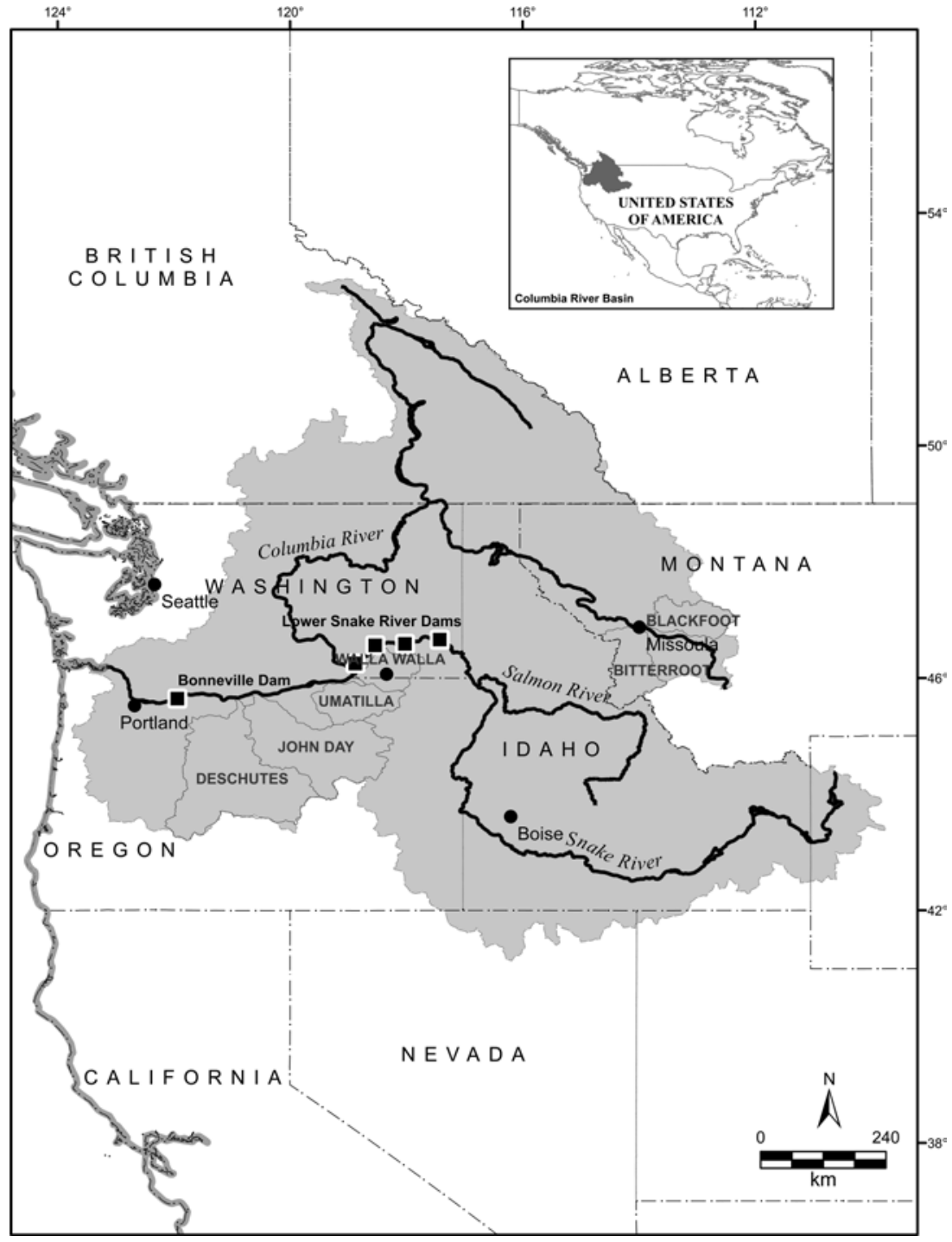

Figure 1.4a Columbia River and selected tributaries

et al., 1997). The Columbia differs from the Colorado because it lacks a lead federal agency in water planning; it also lacks an interstate compact to apportion water rights between the upper and lower basin states, despite an attempt from 1950 to 1968 focused principally on coordinating 


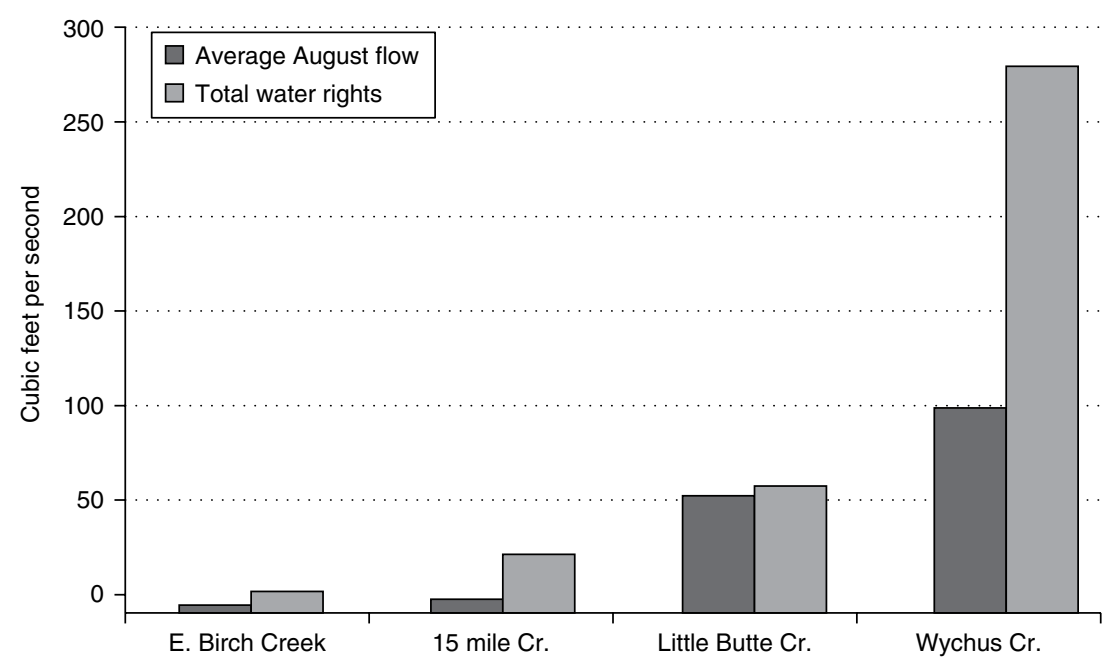

Figure 1.4b River basin closure in the tributaries of the Columbia: average August streamflows in selected tributaries of the Columbia River, compared with total water rights

hydropower generation between private and public entities (National Research Council, 2004). The FCRPS establishes a federal overlay in water management for power and conservation activities under the 1980 Northwest Power Act. Tribes also have substantial property rights, including 1855 Stevens Treaty rights to salmon harvests (Bark et al., 2012). The 1964 international treaty shares flood control and hydropower benefits between Canada and the United States, but is silent on water quantity, ecosystem protection and other matters. An interstate apportionment treaty has been elusive in the US portion of the Columbia Basin. Federal energy and environmental laws have facilitated interstate coordination through the 1980 Northwest Power Act and the authorization of the Bonneville Power Administration as a quasi-governmental energy utility. The region-wide scope of both entities influences water-related planning, salmon recovery and infrastructure management.

\section{Murray-Darling}

The Murray-Darling Basin (Figure 1.5a) is more than 1 million $\mathrm{km}^{2}$ and 14 per cent of Australia's landmass, spanning four states and one territory. The Great Dividing Range forms the eastern boundary and feeds the Murray and Murrumbidgee Rivers. The Darling River of 


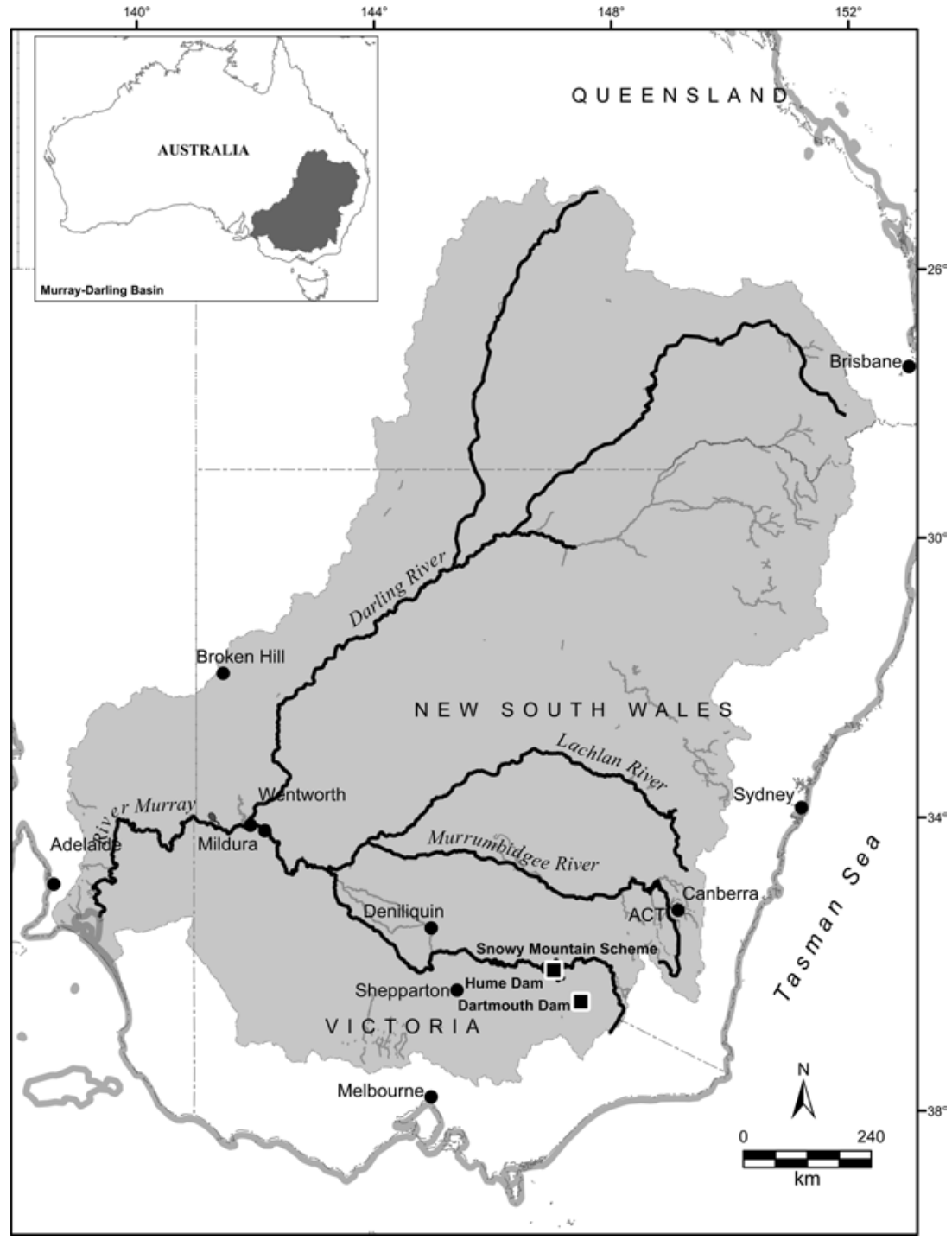

Figure 1.5a Murray-Darling River

Southern Queensland and New South Wales is influenced by a different set of hydroclimatic influences with higher temperatures and rainfall variability than the Southern Murray system (CSIRO, 2008). The three rivers are the longest in Australia, with an inflow of $32800 \mathrm{GL}$ and an annual average outflow of $12500 \mathrm{GL}$ to the Murray Mouth under 
pre-development conditions. The Darling contributes approximately 2399 GL of the 12503 reaching the Mouth (Murray-Darling Basin Authority, 2010). Outflows have been reduced to an annual average of $5100 \mathrm{GL}$ after upstream development with droughts and diversions leading to zero outflows and dredging in 1981 and for several years after 2002. Both the technology and terminology for water use differ in the Murray-Darling. Current water use patterns comprise 10940 GL in watercourse diversions and $2740 \mathrm{GL}$ in interceptions (farm ponds and plantations).

Storage capacity of almost $22000 \mathrm{GL}$ is distributed across storage reservoirs, principally on the Murray, highlighted by the Hume (completed 1936) and Dartmouth (completed 1979), as well as interbasin transfers routed through the Snowy Mountains Hydro-Electric Scheme. Interannual variability is a hallmark of the river system and the region known as the 'land of drought and flooding rains' based on the famous poem by Dorothea Mackellar. At least 80 of the 240 years since European settlement in the late eighteenth century have been characterized as drought years, with many clustered in sustained droughts, such as those at the turn of both the twentieth (Federation Drought) and twenty-first (Millennium Drought) centuries (Helman, 2009). Prolonged droughts have combined with an almost fourfold increase in water use from the 1930s to 1990s to place the basin under stress. During sustained droughts, there have been prolonged periods of reduced outflows, requiring dredging in 1981 and again starting in 2002 for several years during the Millennium Drought (1997-2009) (see Figure 1.5b). Growth in irrigation demand reduced average outflows at the Murray Mouth from the pre-development to the post-development period (Murray-Darling Basin Authority, 2010); the probability that outflows would decline below $5000 \mathrm{GL}$ increased from a one in 20-year event to once in two years (WGCS, 2010). During the Millennium Drought (1997-2009) the floodplain and wetland ecosystem requirements for flood frequency, duration and volume were not met; inflows were insufficient (after upstream diversions) to keep the river open to the sea without dredging. Environmental assets bore a disproportionate share of reductions in water availability despite declines in irrigation water use.

The Australian Constitution reserves water allocation authority for the states, which allocate water via statutory water plans. The 1914-15 River Murray Waters Agreement divided water among the three main states in the Southern Murray: Victoria, New South Wales and South Australia. The Murray-Darling Basin Agreement (1992) expanded cooperation to Queensland and the Australian Capital Territory. The Council of Australian Governments adopted a framework for reform in 1994, which 


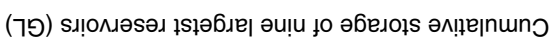

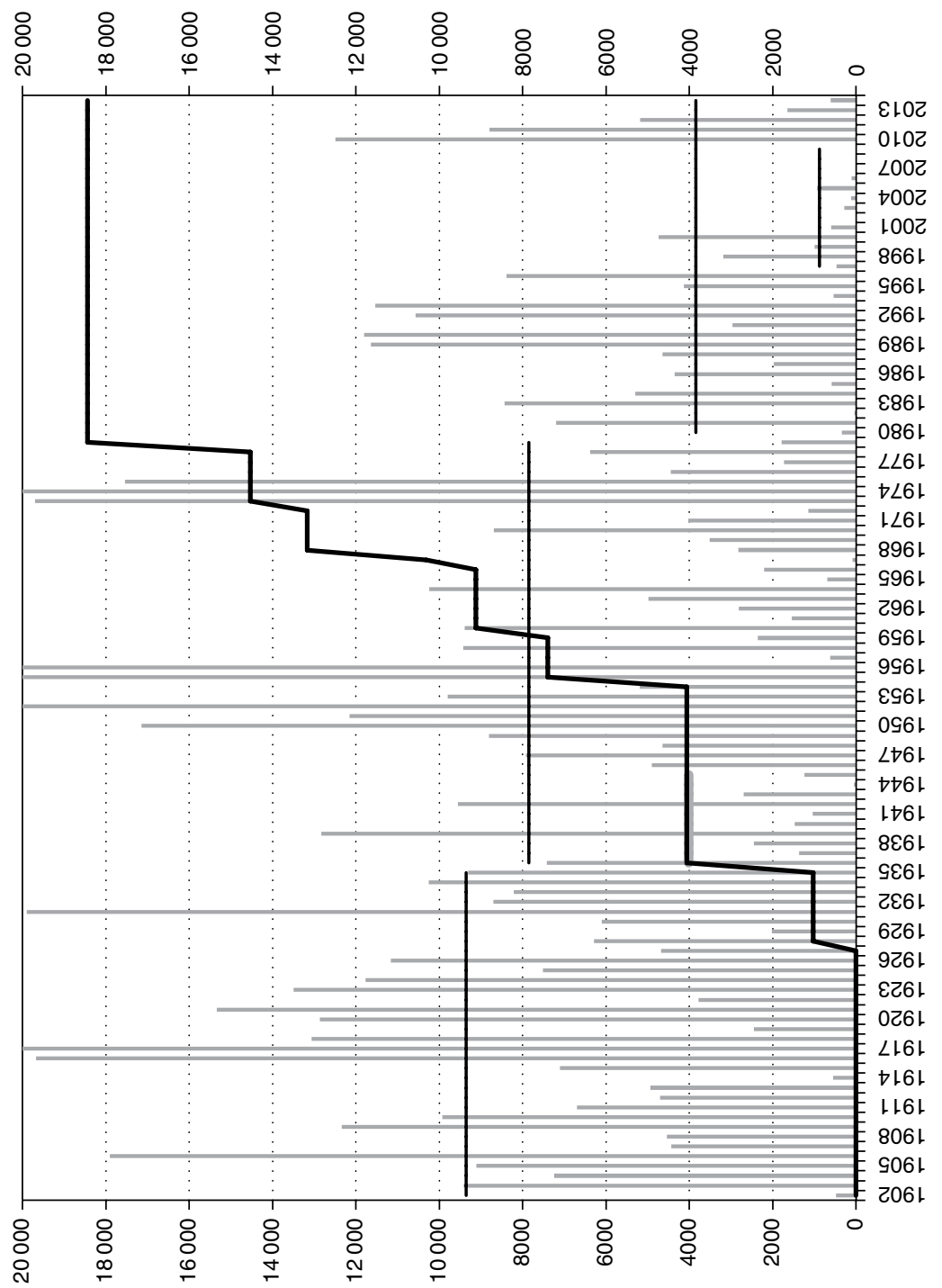

(7פ) Sмојџпо деәК дәңем

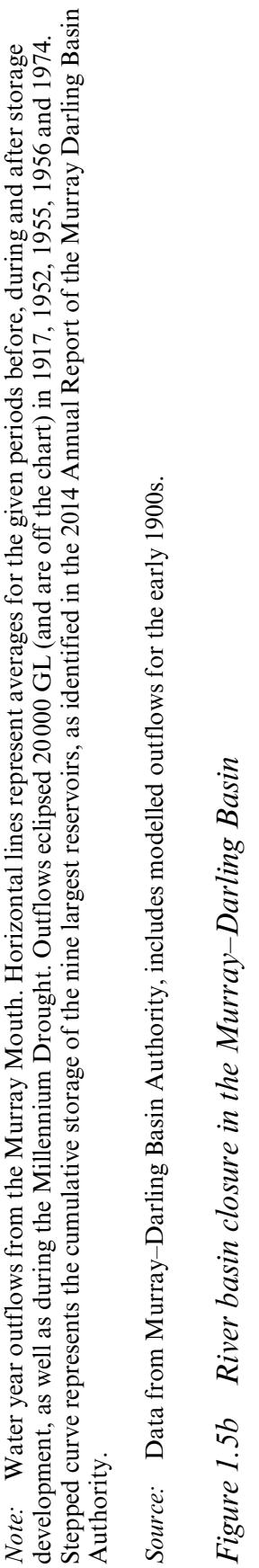


led to the subsequent audit of water use and a cap on diversions in 1995. The 2004 National Water Initiative (NWI) - an intergovernmental agreement among four states, one territory and the Commonwealth government - streamlined the reforms with an aim of harmonizing tradable water rights systems across state jurisdictions. In 2007, the Commonwealth Water Act set out an overarching objective to optimize social, ecological and economic outcomes of water use in the basin by establishing sustainable diversion limits based on basin-wide environmental needs. In so doing, it established a federal authority - the Murray-Darling Basin Authority - to implement these provisions by invoking new Constitutional authority (see Chapter 5 in this volume). A comprehensive basin plan was adopted into statute in 2012 by Parliament. In 2014, the National Water Commission (established under the NWI) was disbanded as part of a change in government.

These three rivers share a defining set of challenges but have experienced varied success with recent water allocation reforms. This book uses transaction costs analysis and common pool resource governance to explore and explain these divergent outcomes, as well as the principles, lessons and implications from the similarities and differences in their institutional evolution and performance.

\section{BOOK OVERVIEW AND STRUCTURE OF THE ARGUMENT}

Closed river basins in Western North America and Australia bring the global water crisis into focus at multiple scales, from the local impacts on water users and communities to the transboundary interdependencies and trade-offs across political borders from states to countries. In this context, efforts to claw back water for the environment over the past two decades have lagged, competition has intensified, and conflicts have lingered despite political and economic pressure for reallocation. This lag stems in part from transaction costs, which remain poorly understood in our theories and policy analysis of institutional change in water reform, particularly at the fuzzy intersection of public and private interests within water allocation.

The book aims to address this gap in the theory and evidence on collective action in cap-and-trade water allocation reforms, by linking conceptual and analytical perspectives from transaction costs and common pool resource studies. It will do so by applying conceptual advances, empirical evidence and methodological innovations to three case studies of marketbased water reform with varying levels of success. 
The objectives of the book are addressed as follows. Chapter 2 introduces an analytical framework for examining the evolution and performance of water allocation institutions. I synthesize concepts, evidence and methodological approaches in transaction costs analysis by: framing the challenge of adaptation as a challenge of reallocation, introducing the transaction as a unit of analysis, and examining complex, mixed property rights for common pool resources. I draw on four theoretical traditions in transaction costs and institutional analysis: Coase, Ostrom, Williamson, and North, as well as several important property rights economists who have focused on water (Anderson and Libecap to name a couple). A key insight lies in the concept of path dependency: the fact that past decisions enable some options and foreclose others, demonstrating the importance of interactions between the costs of implementing transactions within the prevailing institutional setting versus the costs of institutional transitions to water rights systems and river basin governance institutions. In this context, I build on recent efforts to elaborate adaptive efficiency as a multi-dimensional performance criterion for assessing the evolution and performance of water allocation reforms in a transaction costs world.

Chapter 3 traces the path dependence of water resource development and institutional reform across the three river basins to frame the past trajectories, current trade-offs and future prospects of water allocation reforms. It highlights three important institutional choices and technological innovations associated with water rights systems, irrigation supply organizations and interstate apportionment agreements. It shows that the assumptions guiding initial water allocation decisions no longer appear valid: the notion of a 'stationary' water supply, the predominance of irrigation and the acceptable level of impacts on the environment. The notion of 'lock-in' costs is used to understand the institutional friction of transaction costs and the intertemporal trade-offs of path dependent policy reforms in the early phases of cap-and-trade water allocation reforms across the linked processes of capping, allocating and trading. The Colorado River Basin demonstrates the lock-in consequences of past decisions; allocation decisions taken in the early twentieth century were based on optimistic supply scenarios that guided water resource development and created unexpected (downstream) winners and (upstream and environmental) losers. This lock-in is a starting point to consider reform lessons from promising examples in the Columbia and Murray-Darling Basins, as well as recent breakthroughs in the Colorado itself.

Chapter 4 analyzes the emergence, evolution and performance of markets for environmental flows in the Columbia Basin. It measures and explains transaction costs and adaptive efficiency across 13 watershed-level 
case studies in four US states over an eight-year period from 2003-2010. The performance of emerging markets for environmental flows varies as much within states as across them, due to importance of local institutions for water rights reform and the multilevel collective action at the field, state and federal levels to coordinate market transactions with wider institutional frameworks for water planning, water banking and so on. Empirical analysis of water reallocation for environmental flows in the Columbia Basin is used to demonstrate these conceptual issues and provide methodological tools to measure and manage the transaction costs of water rights reform. Across the three basins, diversion limits have been based on historic use patterns, which engrained unsustainable extraction levels in property rights institutions.

Chapter 5 examines the maturation of markets and provision of multiple water-related public goods in the Murray-Darling, each with different communities of interest, politics and economies of scale. I examine efforts to 'scale up' water allocation reform across three interdependent elements: market-based water rights reform, the establishment (and adaptation) of diversion limits, and the recovery of water for the environment to address the consequences of overallocation. The challenge of scaling up trading activity and recovering water for the environment exposes the need for substantial, sustained and multi-level governance capacity. This capacity depends on a mixture of formal and informal institutions coordinated by polycentric governance arrangements, highlighting the importance of institutional mechanisms to balance subsidiarity (the local capacity necessary in the Columbia example) with complementarity (the diverse vertical and horizontal coordination mechanisms to reconcile tasks and trade-offs that span jurisdictions and interests).

The final chapter reflects on the lessons for the theory and practice of water allocation reform in rivers under pressure, with implications for future studies to diagnose governance challenges, and design and sequence the reforms needed for adaptive efficiency.

\section{NOTES}

1. Although the US has been able to decouple population growth and water use (Gleick, 2003).

2. Ostrom et al. focus on 'global commons' but also refer to large international rivers as an example of large-scale common pool resources.

3. These correspond roughly to command-and-control regulation, private property and community-based management, respectively.

4. IWRM is a process which promotes the coordinated development and management of 
water, land and related resources, in order to maximize the resultant economic and social welfare in an equitable manner without compromising the sustainability of vital ecosystems (Global Water Partnership, 2000).

5. See Chapter 2 for a thorough consideration of rivalling definitions of transaction costs, ranging from broad and dynamic to narrow and static.

\section{REFERENCES}

ANDERSON, T.L. and LEAL, D.R. 2001. Free Market Environmentalism. New York: Palgrave Macmillan.

ANDERSON, T.L., SCARBOROUGH, B. and WATSON, L.R. 2012. Tapping Water Markets. London: Routledge.

ANDERSSON, K.P. and OSTROM, E. 2008. Analyzing decentralized resource regimes from a polycentric perspective. Policy Sciences, 41, 71-93.

BAKKER, K. 2014. The business of water: market environmentalism in the water sector. Annual Review of Environment and Resources, 39, 469-94.

BARK, R. H., GARRICK, D. E., ROBINSON, C. J. and JACKSON, S. 2012. Adaptive basin governance and the prospects for meeting Indigenous water claims. Environmental Science \& Policy, 19, 169-177.

BENNETT, J. 2005. The Evolution of Markets for Water: Theory and Practice in Australia. Edward Elgar Publishing, Cheltenham, UK.

BLOMQUIST, W. and SCHLAGER, E. 2005. Political pitfalls of integrated watershed management. Society and Natural Resources, 18, 101-17.

BLUMM, M.C. 1992. Fallacies of free market environmentalism. Harvard Journal of Law and Public Policy, 15, 371.

CAREY, J.M. and SUNDING, D.L. 2001. Emerging markets in water: a comparative institutional analysis of the Central Valley and Colorado-Big Thompson projects. Natural Resources Journal, 41, 283-328.

CHALLEN, R. 2000. Institutions, Transaction Costs and Environmental Policy. Cheltenham, UK and Northampton, MA, USA: Edward Elgar Publishing.

CHOPRA, K.R. and MILLENNIUM ECOSYSTEM ASSESSMENT RESPONSES WORKING GROUP. 2005. Ecosystems and Human Well-Being: Policy Responses: Findings of the Responses Working Group. Washington, DC: Island Press.

COMMONWEALTH SCIENTIFIC AND INDUSTRIAL RESEARCH ORGANISATION (CSIRO). 2008. Water Availability in the Murray-Darling Basin Report. Canberra: CSIRO Publishing.

CONCA, K. 2006. Governing Water: Contentious Transnational Politics and Global Institution Building. Cambridge, MA: MIT Press.

CONGRESSIONAL RESEARCH SERVICE. 2009. 35 years of water policy: the 1973 National Water Commission and present challenges. In: CODY, B.A. and CARTER, N.T. (eds). Washington, DC.

COX, M., ARNOLD, G. and TOMÁS, S.V. 2010. A review of design principles for community-based natural resource management. Ecology \& Society, 15(4), 38.

DEAKIN, A. 1885. Royal Commission on Water Supply, first progress report, irrigation in Western America. Available at: http://www.dwu.edu/library/ 
environmental_history/ElectronicArchivesPDFDocuments/WaterConserva tion\&Development/deakinroyalcommissiononwatersuupply.pdf.

EASTER, W.K., ROSEGRANT, M.W. and DINAR, A. 1998. Markets for Water: Potential and Performance. Boston: Kluwer Academic Publisher.

EASTER, K.W. AND HUANG, Q. 2014. Water Markets for the 21st Century: What Have We Learned? Dordrecht: Springer.

GARRICK, D., WHITTEN, S. and COGGAN, A. 2013. Understanding the evolution and performance of water markets and allocation policy: a transaction costs analysis framework. Ecological Economics, 82, 195-205.

GLEICK, P.H. 2003. Global freshwater resources: soft-path solutions for the 21st Century. Science, 302, 28 November, 1524-28.

GLENNON, R.J. 2010. Unquenchable: America's Water Crisis and What To Do About It. Washington, DC: Island Press.

GRAFTON, R.Q. and HORNE, J. 2014. Water markets in the Murray-Darling Basin. Agricultural Water Management, 145 (2014), 61-71.

GRAFTON, R.Q., LIBECAP, G., MCGLENNON, S., LANDRY, C. and O'BRIEN, B. 2011. An integrated assessment of water markets: a cross-country comparison. Review of Environmental Economics and Policy, 5 (2), 219-39.

GRAFTON, R.Q., LIBECAP, G.D., EDWARDS, E.C., O'BRIEN, R.J. and LANDRY, C. 2012. Comparative assessment of water markets: insights from the Murray-Darling Basin of Australia and the Western USA. Water Policy, $14,175$.

HAMLET, A.F. 2003. The role of transboundary agreements in the Columbia River Basin: an integrated assessment in the context of historic development, climate, and evolving water policy. Climate and Water, 16, 263-89.

HANAK, E. and STRYJEWSKI, E. 2012. California's water market, by the numbers: update 2012. Public Policy Institute of California.

HELMAN, P. 2009. Droughts in the Murray Darling Basin since European Settlement. Griffith Centre for Coastal Management Research Report No. 100. Canberra: Murray-Darling Basin Authority.

HOWE, C.W., BOGGS, C. and BUTLER, P. 1990. Transactions costs as determinants of water transfers. University of Colorado Law Review, 61(2), 393-405.

INTERNATIONAL CONFERENCE ON WATER AND THE ENVIRONMENT (ICWE). 1992. The Dublin Statement on Water and Sustainable Development. Dublin: World Meteorological Organization. Available at: http:// www.wmo.int/pages/prog/hwrp/documents/english/icwedece.html.

INTERNATIONAL WATER MANAGEMENT INSTITUTE. 2005. Planning for Environmental Flows. Water Policy Issue Paper 15. IWMI, Sri Lanka. Available at: http://www.iwmi.cgiar.org/Publications/Water_Policy_Briefs/ PDF/wpb15.pdf.

MAESTU, J. 2013. Water Trading and Global Water Scarcity: International Experiences. Washington, DC: RFF Press.

MARSHALL, G. 2005. Economics for Collaborative Environmental Management: Renegotiating the Commons. Abingdon: Routledge.

MARSHALL, G. 2008. Nesting, subsidiarity, and community-based environmental governance beyond the local scale. International Journal of the Commons, 2, 75-97.

MCGINNIS, M.D. and OSTROM, E. 2012. Reflections on Vincent Ostrom, public administration, and polycentricity. Public Administration Review, 72, $15-25$. 
MEINZEN-DICK, R. 2007. Beyond panaceas in water institutions. Proceedings of the National Academy of Sciences, 104, 15200-15205.

MEINZEN-DICK, R. 2014. Property rights and sustainable irrigation: A developing country perspective. Agricultural Water Management.

MOLLE, F. 2008. Nirvana concepts, narratives and policy models: insights from the water sector. Water Alternatives, 1, 131-56.

MOLLE, F. 2009. River-basin planning and management: the social life of a concept. Geoforum, 40, 484-94.

MOLLE, F., WESTER, P. and HIRSH, P. 2010. River basin closure: processes, implications and responses. Agricultural Water Management, 97, 569-77.

MOSS, T. 2004. The governance of land use in river basins: prospects for overcoming problems of institutional interplay with the EU Water Framework Directive. Land Use Policy, 21, 85-94.

MOSTERT, E., CRAPS, M. and PAHL-WOSTL, C. 2008. Social learning: the key to integrated water resources management? Water International, 33, 293-304.

MURRAY-DARLING BASIN AUTHORITY (MDBA). 2010. Guide to the Proposed Basin Plan. Canberra: Murray-Darling Basin Authority.

NATIONAL RESEARCH COUNCIL. 1992. Water Transfers in the West: Efficiency, Equity, and the Environment. Washington, DC: National Academies Press.

NATIONAL RESEARCH COUNCIL. 2004. Managing the Columbia River Instream Flows, Water Withdrawals, and Salmon Survival.

NATIONAL RESEARCH COUNCIL. 2007. Colorado River Basin Water Management Evaluating and Adjusting to Hydroclimatic Variability. Washington, D.C: NRC.

NATIONAL WATER COMMISSION (NWC). 1973. Water Policies for the Future: Final Report to the President and to the Congress of the United States by the National Water Commission. Washington, DC: National Water Commission.

NEUMAN, J.C. 2004. The good, the bad, and the ugly: the first ten years of the Oregon Water Trust. Nebraska Law Review, 83, 432.

NORTHWEST POWER AND CONSERVATION COUNCIL (NPCC). 2014. Fiscal Year 2013 Annual Report: The State of the Columbia River Basin. NPCC, Portland. Available at: https://www.nwcouncil.org/reports/ financial-reports/2014-01/.

OECD. 2011. Water Governance in OECD Countries: A Multi-Level Approach. Paris: OECD Publishing.

OECD. 2012. OECD Environmental Outlook to 2050. Paris: OECD Publishing.

OLMSTEAD, S.M. 2010. The economics of managing scarce water resources. Review of Environmental Economics and Policy, 4(2), 179-98.

OSTROM, E. 1990. Governing the Commons: The Evolution of Institutions for Collective Action. Cambridge: Cambridge University Press.

OSTROM, E. 2009. Understanding Institutional Diversity. Princeton, NJ: Princeton University Press.

OSTROM, V., TIEBOUT, C.M. and WARREN, R. 1961. The organization of government in metropolitan areas: a theoretical inquiry. American Political Science Review, 55, 831-42.

RITTEL, H.W. and WEBBER, M.M. 1973. 2.3 planning problems are wicked. Polity, 4, 155-69. 
ROSE, C.M. 1990. Energy and efficiency in the realignment of common-law water rights. Journal of Legal Studies, 261-96.

ROSEGRANT, M.W. and BINSWANGER, H.P. 1994. Markets in tradable water rights: potential for efficiency gains in developing country water resource allocation. World Development, 22(11), 1613-25.

SALIBA, B. and BUSH, D.B. 1987. Water Markets in Theory and Practice: Market Transfers, Water Values, and Public Policy. Westview Press.

SCHEWE, J., HEINKE, J., GERTEN, D., HADDELAND, I., ARNELL, N.W., CLARK, D.B. ... and KABAT, P. 2014. Multimodel assessment of water scarcity under climate change. Proceedings of the National Academy of Sciences, 111(9), 3245-50. Available at: http://www.pnas.org/content/111/9/3245.full. pdfMar.

SCHLAGER, E. and BLOMQUIST, W.A. 2008. Embracing Watershed Politics. Boulder, CO: University Press of Colorado.

SCHLAGER, E. and OSTROM, E. 1992. Property-rights regimes and natural resources: a conceptual analysis. Land Economics, 68, 249-62.

SCHOESSLER, M.A., BLUMM, M.C. and SWIFT, B.M. 1997. A Survey of Columbia River Basin Water Law Institutions and Policies: Report to the Western Water Policy Review Advisory Commission. Denver, CO: Western Water Policy Review Advisory Commission.

THIEL, A. 2014. Rescaling of resource governance as institutional change: explaining the transformation of water governance in southern Spain. Environmental Policy and Governance, 24, 289-306.

US BUREAU OF RECLAMATION. 2012. Colorado River Basin Water Supply and Demand Study. Washington, DC: Department of Interior.

US BUREAU OF RECLAMATION. 2013. Upper Colorado Region Water Resources Group Annual Operating Plans. Washington, DC: Department of Interior.

US BUREAU OF RECLAMATION. 2015. Moving Forward to Address the Challenges Identified in the Colorado River. Basin Water Supply and Demand Study. Washington, DC: Department of Interior.

US DEPARTMENT OF THE INTERIOR (DOI). 2007. Record of decision: Colorado River interim guidelines for lower basin shortages and the coordinated operations for Lake Powell and Lake Mead.

VOROSMARTY, C.J., MCINTYRE, P.B., GESSNER, M.O., DUDGEON, D., PRUSEVICH, A., GREEN, P., GLIDDEN, S., BUNN, S.E., SULLIVAN, C.A., REIDY LIERMANN, C. and DAVIES, P.M. 2010. Global threats to human water security and river biodiversity. Nature, 467, 555-61.

WENTWORTH GROUP OF CONCERNED SCIENTISTS (WGCS). 2010. Sustainable Diversions in the Murray-Darling Basin: An analysis of the options for achieving a sustainable diversion limit in the Murray-Darling Basin. Canberra, Australia.

WOODHOUSE, C.A., GRAY, S.T. and MEKO, D.M. 2006. Updated streamflow reconstructions for the Upper Colorado River basin. Water Resources Research, 42, 1-16.

WORLD ECONOMIC FORUM (WEF). 2013. Global Risks 2013, 8th edition. Davos, Switzerland.

WORLD ECONOMIC FORUM (WEF). 2015. Global Risks 2015, 10th edition, Davos, Switzerland. 